\title{
ISOLATION OF EXTRAINTESTINAL PATHOGENIC ESCHERICHIA COLI FROM DIARRHEIC DOGS AND THEIR ANTIMICROBIAL RESISTANCE PROFILE
}

\author{
Cleber Jacob Silva de Paulaㅜ; José Moacir Marin²* \\ 'Programa de Microbiologia Agropecuária, Faculdade de Ciências Agrárias e Veterinárias, Universidade Estadual Paulista, \\ Jaboticabal, SP, Brasil; ${ }^{2}$ Departamento de Morfologia, Estomatologia e Fisiologia, Faculdade de Odontologia de \\ Ribeirão Preto, Universidade de São Paulo, Ribeirão Preto, SP, Brasil
}

Submitted: August 01, 2007; Returned to authors for corrections: February 29, 2008; Approved: July 06, 2008.

\section{SHORT COMMUNICATION}

\begin{abstract}
From January to December 2006, 92 Escherichia coli isolates from 25 diarrheic dogs were analyzed by screening for the presence of adhesin-encoding genes ( $p a p$, sfa, afa), hemolysin and aerobactin genes. Virulence gene frequencies detected in those isolates were: $12 \%$ pap, $1 \% s f a, 10 \%$ hemolysin and $6.5 \%$ aerobactin. Ten isolates were characterized as extraintestinal pathogenic E. coli (ExPEC) strains; all showed a multidrug resistance phenotype that may represent a reason for concern due the risk of dissemination of antimicrobial resistant genes to the microbiota of human beings.
\end{abstract}

Key-words: Escherichia coli, ExPEC, dog, antimicrobial resistance, multidrug resistance.

Dogs have been proposed as a possible reservoir of the virulent Escherichia coli strain that causes extraintestinal infections in humans; the bacterium has been considered an extraintestinal pathogenic E. coli (ExPEC) $(2,6,11)$. This hypothesis is based on several lines of evidence, including, (i) the documented similarities between certain canine and human urinary tract infections (UTI) isolates of $E$. coli concerning virulence factors (VFs) including adhesins, fimbriae, hemolysin, and aerobactin, that participate in the pathogenesis of the bacterium $(6,11,14,15)$, (ii) the observation that in dogs with UTI the infecting E. coli strains came from their own fecal microbiota $(7,11)$, (iii) the high prevalence of UTI-associated VFs among canine fecal E. coli isolates $(7,14)$.

Although antimicrobial therapy is an important tool for the treatment of these infections, resistance to antimicrobials is widespread and constitutes a great concern of veterinary medicine (5). Indeed, a close relationship between the use of antimicrobial agents for the treatment of infections in animals and levels of observed resistance exists $(1,5)$. Bacteria selected for antimicrobial use in animal pets, when reaching human hosts, may exchange antimicrobial resistance genes with those of normal bacteria resident on or in these hosts (5). Since the antimicrobial classes routinely used for treatment of human infections are often also used for animal therapy, the risk of the transfer of their resistance genes to man, requires continuous evaluation. Thus, the objective of the present study was the isolation of ExPEC strains from the feces of diarrheic dogs and the evaluation of their susceptibility to 12 antimicrobial agents of possible human use.

To this effect, twenty-five diarrheic dogs were examined after arrival for clinical consultation in a private clinic in the city of Ituverava, State of São Paulo, Brazil, between January and December 2006. Samples were collected under the supervision of a veterinarian, using a rectal sterile cotton swab, placed in Stuart transport medium, and immediately processed in the laboratory by transfer to MacConkey agar (Mac-Difco Laboratories, Detroit, USA) and incubation for $24 \mathrm{~h}$ at $37^{\circ} \mathrm{C}$. At least 5 colonies, isolated from each plate, were submitted to further analysis by standard methods for $E$. coli identification (9). E. coli isolates were grown overnight in nutrient broth (Sigma

*Corresponding Author. Mailing address: Departamento de Morfologia, Estomatologia e Fisiologia, Faculdade de Odontologia de Ribeirão Preto, Avenida do Café s/n, Campus USP, Ribeirão Preto, Brasil, 14040-904. E-mail: jmmarin@forp.usp.br 
Chemical Co, St Louis, USA) at $37^{\circ} \mathrm{C}$, and test for the presence of pap, sfa and afa genes using the polymerase chain reaction protocol of Le Bouguenec et al. (10). DNA templates were prepared by pelleting $1 \mathrm{ml}$ of each culture by centrifugation $(12000 \mathrm{~g})$, resuspension in $250 \mu \mathrm{l}$ of sterile distilled water and boiling for $10 \mathrm{~min}$. After renewed centrifugation, supernatants were used for PCR in an Eppendorf Mastercycler (Eppendorf AG, Hamburg, Germany). Pap, sfa and $a f a$ genes were detected using primers and PCR conditions according to the above protocol. The amplified DNA products were separated by electrophoresis on $1.5 \%$ agarose gel, stained with ethidium bromide and examined under ultraviolet light. Hemolysin production was assayed by growing the isolates overnight (16 h), at $37^{\circ} \mathrm{C}$ in Luria-Bertani Broth (LB); $50 \mu 1$ samples were spotinoculated on a sheep blood agar base, incubated at $37^{\circ} \mathrm{C}$ overnight; hemolysin production was verified by the presence of a clear halo of hemolysis around the inoculated site. Aerobactin was assayed by growing isolated strains on LB medium containing $200 \mu \mathrm{M}$ of $\alpha-\alpha$ dipyridyl at $37^{\circ} \mathrm{C}$ for $24 \mathrm{~h}$, without shaking. Produced growths were spun for $3 \mathrm{~min}$ at 12000 $\mathrm{g}$, supernatants were filtered through a nitrocellulose membrane $(0.22 \mu \mathrm{m})$, and $50 \mu \mathrm{l}$ aliquots of the filtrate added to orifices made in LA medium previously seeded with strain LG 1522 (4). Plates were incubated at $37^{\circ} \mathrm{C}$ for $48 \mathrm{~h}$ and aerobactin production visualized by the growth of strain LG 1522 around the orifices. Antimicrobial susceptibility of ExPEC isolates was tested by the disk diffusion method according to National Committee for Clinical Laboratory Standards (12), using commercial disks
(Cefar, São Paulo, Brasil), loaded as follows: nalidixic acid (30 $\mu \mathrm{g})$, amikacin $(30 \mu \mathrm{g})$, amoxicillin $(10 \mu \mathrm{g})$, amoxicillin-clavulanic acid $(30 \mu \mathrm{g})$, ampicillin $(10 \mu \mathrm{g})$, cephalothin $(30 \mu \mathrm{g})$, ceftriaxone $(30 \mu \mathrm{g})$, ciprofloxacin $(5 \mu \mathrm{g})$, cotrimoxazole $(25 \mu \mathrm{g})$, streptomycin $(10 \mu \mathrm{g})$, gentamicin $(10 \mu \mathrm{g})$ and tetracycline $(30 \mu \mathrm{g})$. E. coli reference strains ATCC 25922 and ATCC 35218 were used for strain quality control.

During the 12 month-survey, 25 fecal samples from diarrheic dogs were cultured; $92 \mathrm{E}$. coli strains were isolated and submitted to PCR to detect pap, sfa and afa genes, as well as to traditional methods to detect hemolysin and aerobactin. The isolates possessed genes with combinations of adhesins (P and S fimbriae), an iron acquisition system (aerobactin) and toxins (hemolysin), nowadays collectively regarded as extraintestinal virulence factors (Table 1). Twelve strains carrying those genes were found, 11 carrying the pap gene, one the $s f a$ gene, 9 showing hemolysin, and 6 the aerobactin system. Ten of the 12 strains presented two or more virulence factors; according Johnson et al. (8), they could be classified as ExPEC strains. The low number (11\%) of ExPEC strains isolated from the feces of diarrheic dogs, was lower than the amount reported by Johnson et al. (6), who worked with $E$. coli strains isolated at random from healthy or diarrheic dogs. The amounts of the aerobactin gene, agreed with those reported by Johnson et al. (7) but were lower than those reported by Yuri et al. (14).

Resistance to streptomycin, nalidixic acid, tetracycline, cephalothin and amoxicillin was most frequently observed

Table 1. Virulence factors and antimicrobial resistance of ExPEC isolated from feces of diarrheic dogs in Ituverava, State of São Paulo, Brazil.

\begin{tabular}{|c|c|c|c|c|c|c|}
\hline \multirow{2}{*}{ Isolates } & \multicolumn{6}{|c|}{ Virulence Factors } \\
\hline & pap & $s f a$ & $a f a$ & Hemolysin & aerobactin & Resistance Phenotype ${ }^{* * *}$ \\
\hline $27.1^{*}$ & + & $-* *$ & - & - & - & tet, gen, nal, cip. \\
\hline 30.3 & + & - & - & + & + & amp, amo, cep, tet, gen, str, nal, sut. \\
\hline 35.1 & + & - & - & + & + & amo, ami, cep, str. \\
\hline 37.1 & + & - & - & + & + & tet, gen, str. \\
\hline 42.1 & + & - & - & + & - & cep, cef, tet, str, nal. \\
\hline 42.2 & + & - & - & - & + & str, ami, nal. \\
\hline 42.3 & + & - & - & + & - & amp, amo, tet, gen, str, ami, nal, cip, sut. \\
\hline 50.3 & - & + & - & + & + & str, nal, amo. \\
\hline
\end{tabular}

*- Isolate number **-negative; ***-Antimicrobials: Tet-tetracycline; Gen-gentamicin; Nal-nalidixic-acid; Cip- ciprofloxacin; Amo-amoxicillin; Cep-cephalothin; Str-streptomycin; Amp-ampicillin; Sut-cotrimoxazole; Ami-amikacin; Cef-ceftriaxone; ****-positive strains/ total strains. 
among our ExPEC isolates. This result agrees with data showing such resistance to be common among $E$. coli strains isolated from companion animals $(3,13)$. All isolates studied by us showed resistance to at least three antimicrobial drugs; they could therefore be considered as being multidrug-resistant.

Pets are natural reservoirs of several organisms, in special of ExPEC strains potentially capable of infecting human beings (6). Close relationship between household pets and humans, therefore provide conditions favorable for bacteria transmission by direct contact (petting, licking, physical injuries, etc), at the domestic environment (5). Children are at greater risk than adults due to their closer physical contact with dogs as well as with contaminated households. In conclusion, the present study shows the presence of ExPEC strains in bacterial isolates from diarrheic dogs, all multidrug-resistant strains, their possible contamination of human beings constituting a reason for concern.

\section{ACKNOWLEDGEMENTS}

The authors thank FAPESP for financial support.

\section{RESUMO}

\section{Isolamento de Escherichia coli extraintestinal patogênica de cachorros diarréicos e seu perfil de resistência antimicrobiana}

Entre Janeiro e dezembro de 2006, 92 cepas de Escherichia coli isoladas de 25 cachorros diarréicos foram analisadas para a detecção de genes codificadores de adesinas ( $p a p, s f a$ e $a f a$ ), hemoisina e aerobactina. As freqüências dos genes de virulência detectadas nestas cepas foram: $12 \%$ pap, $1 \%$ sfa, $10 \%$ hemolisina e $6,5 \%$ aerobactina. Dez cepas foram caracterizadas como $E$. coli extraintestinal patogênica (ExPEC) e todas as cepas apresentaram um fenótipo de multiresistência, o que pode representar um motivo de preocupação, por causa do risco de disseminação de genes de resistência a drogas antimicrobianas para a microbiota dos seres humanos.

Palavras-chave: Escherichia coli, ExPEC, cachorro, resistência antimicrobiana, multiresistência.

\section{REFERENCES}

1. Aarestrup, F.M. (2005). Veterinary drug usage and antimicrobial resistance in bacteria of animal origin. Basic Clin. Pharmacol. Toxicol., 96, 271-281.

2. Beutin, L. (1999). Escherichia coli as a pathogen in dogs and cats. Vet. Res., 30, 285-298.

3. Carattoli, A.; Lovari, S.; Franco, A.; Cordaro, G.; Matteo, P.D.; Battisti, A. (2005). Extended-spectrum $\beta$-lactamase in Escherichia coli isolated from dogs and cats in Rome, Italy, from 2001 to 2003. Antimicrob. Agents Chemother., 49, 833-835.

4. Carbonetti, N.H.; Williams, P.H. (1985). Detection of synthesis of the hydroxamate siderophore aerobactin by pathogenic isolates of Escherichia coli In: Sussman, M. (Ed). The virulence of Escherichia coli. Reviews and methods. Orlando, Academic Press, p. 419-424.

5. Guardabassi, L.; Schwarz, S.; Lloyd, D.H. (2004). Pet animals as reservoirs of antimicrobial-resistant bacteria. J. Antimicrob. Chemother., 54, 321-332.

6. Johnson, J.R.; Stell, A.L.; Delavari, P. (2001a). Canine feces as a reservoir of extraintestinal pathogenic Escherichia coli. Infect. Immun., 69, 1306-1314.

7. Johnson, J.R.; Delavari, P.; Stell, A.L.; Whittam, T.S.; Carlino, U.; Russo, T.A. (2001b). Molecular comparison of extraintestinal Escherichia coli isolates of the same electrophoretic lineages from humans and domestic animals. J. Infect. Dis., 183, 154-159.

8. Johnson, J.R.; Kuskowski, M.A.; Smith, K.; O’Bryan, T.T.; Tatini, S. (2005). Antimicrobial-resistant and extraintestinal pathogenic Escherichia coli in retail foods. J. Infect. Dis., 191, 1040-1049.

9. Koneman, E.W.; Allen, S.D.; Janda, W.M.; Schreckenberger, P.C.; Winn, W.C. (1997). Color atlas and textbook of diagnostic microbiology, 5 ed. Philadelphia, Lippincott Company, p. 363-393.

10. Le Bouguenec, C.; Archambaud, M.; Labigne, A. (1992). Rapid and specific detection of the pap, afa, and $s f a$ adhesion-encoding operons in uropathogenic Escherichia coli strains by polymerase chain reaction. J. Clin. Microbiol., 30, 1189-1193.

11. Low, D.A.; Braaten, B.A.; Ling, G.V.; Johnson, D.L.; Ruby, A.L. (1988) Isolation and comparison of Escherichia coli strains from canine and human patients with urinary tract infections. Infect. Immun., 56, 2601-2609.

12. National Committee for Clinical Laboratory. (1999). Performance Standards for antimicrobial disk dilution susceptibility test for bacteria isolated from animals approved Standard M31A, v. 19, n. 11. National Committee for Clinical Laboratory Standards, Wayne, P.A.

13. Normand, E.H.; Gibson, N.R.; Reid, S.W.J.; Carmichael, S.; Taylor, D.J. (2000). Antimicrobial-resistance trends in bacterial isolates from companion-animal community practice in the UK. Prev. Vet. Med., 46, 267-278.

14. Yuri, K.; Nakata, K.; Katae, H.; Yamamoto, S.; Hasegawa, A. (1998). Distribution of uropathogenic virulence factors among Escherichia coli strains isolated from dogs and cats. J. Vet. Med. Sci., 60, 287-290.

15. Whittam, T.S.; Wolfe, M.L.; Wilson, R.A. (1989). Genetic relationships among Escherichia coli isolate causing urinary tract infections in humans and animals. Epidemiol. Infect., 102, 37-46. 